\title{
ОСОБЛИВОСТІ ЗАКОНОДАВЧОГО РЕГУЛЮВАННЯ ЗОВНІШНЬОЕКОНОМІЧНОЇ ДІЯЛЬНОСТІ
}

Постановка проблеми. Зовнішньоекономічна діяльність завжди була пріоритетним напрямком господарської діяльності, адже під час здійснення ринкових відносин така діяльність не обмежується лише внутрішньодержавним ринком. 3 метою придбання і реалізації товарів, виконання робіт, надання послуг і здійснення інших видів господарської діяльності суб'єкти господарювання виходять на міжнародний (світовий) ринок, а відтак здійснюють зовнішньоекономічну діяльність.

Налагодження відносин з провідними та найбільш розвинутими країнами світу виведе Україну на принципово новий рівень і тим самим сприятиме удосконаленню вітчизняних процесів виробництва, покращення якості продукції, що підвищить конкурентоспроможність національного товаровиробника. Дані перетворення дадуть змогу створити сприятливі умови інтеграції України на європейський і світовий ринок.

Аналіз останніх досліджень і публікацій. Питанням правового регулювання зовнішньоекономічної діяльності в Україні присвячено багато наукових досліджень. Основні інструменти державного регулювання ЗЕД детально проаналізовані науковцями О. Вишняковим [1], С. Коломацькою [2], О. Костюченком [3], Н. Георгіаді [4], А. Мазаракі [5]. Питання формування структури системи державного регулювання зовнішньоекономічної діяльності висвітлено у працях Д. Авер'янова [6] та інших авторів.

Метою даної статті є аналіз чинних нормативно-правових актів України, що регулюють відносини у сфері здійснення зовнішньоекономічної діяльності, обгрунтування доцільності вдосконалення системи правового регулювання даного виду діяльності з метою формування та функціонування ефективного механізму державного регулювання.

Виклад основного матеріалу. Основні результати дослідження. Формування дієвого механізму нормативно-правового регулювання зв'язків між суб'єктами зовнішньоекономічних відносин, створення правових засад системи державного регулювання зовнішньоекономічної діяльності в Україні, визначення компетенції окремих органів виконавчої влади у реалізації державної політики у сфері зовнішньоекономічної діяльності, а також створення сприятливих умов для здійснення зовнішньоекономічної діяльності є одними із актуальних напрямків нормотворчої діяльності та державної політики України. Нормативно-правове регулювання зовнішньоекономічної діяльності здійснюється низкою актів господарського законодавства загальної сфери дії та спеціального законодавства, що регулює специфічні зовнішньоекономічні відносини. На сучасному етапі розвитку зовнішньоекономічних зв'язків України воно має відіграти важливу роль у зміцненні конкурентоспроможності вітчизняної економіки, іiі інноваційному відновленні, утвердженні сприятливого інвестиційного й підприємницького клімату, модернізації виробництва, інституційною основою якої виступають система нормативно-правових джерел і сукупність органів, що виконують функції зі створення, реалізації та контролю виконання нормативно-правових актів.

Спеціальне законодавство про зовнішньоекономічну діяльність складається 3 законодавчих актів, що мають різну юридичну силу та були створені для регулювання даного виду діяльності (у тому числі й окремих іiі аспектів) та норми, що містяться в нормативно-правових актах загальної сфери дії чи присвячених регулюванню інших видів діяльності та правовідносин, що можуть перетинатися із зовнішньоекономічною діяльністю і таким чином фрагментарно регулюють зовнішньоекономічну діяльність, а саме банківську діяльність, страхування, інвестиційну діяльність (іноземне, спільне інвестування, концесії) та ін. Відтак, систему нормативно-правових актів законодавства, що регулюють зовнішньоекономічну діяльність, умовно можна поділити на загальну частину, що включає нормативно-правові акти, у яких викладені загальні положення зовнішньоекономічної діяльності та спеціальну частину, до якої належать акти законодавства та норми, 
що визначають специфіку здійснення зовнішньоекономічної діяльності, в окремих сферах економіки та на окремих територіях, за участю окремих суб'єктів тощо.

В юридичній літературі зовнішньоекономічна діяльність розглядається як діяльність у сфері розвитку співробітництва з іншими державами у галузі торгівлі, економіки, техніки, культури, туризму. На думку деяких авторів, це особлива форма здійснення суспільно-виробничих зв'язків між окремими державами, між державами і міжнародними організаціями, між міжнародними організаціями у сфері міжнародного економічного співробітництва, яка є предметом вивчення міжнародного економічного права як самостійної галузі міжнародного публічного права.

Господарський кодекс України (далі - ГК України) містить загальні положення правового регулювання зовнішньоекономічних відносин, які закріплені в розд. VII гл. 37 ГК України. Відповідно до ст. 377 ГК України зовнішньоекономічною діяльністю суб’єктів господарювання є господарська діяльність, яка в процесі ії здійснення потребує перетинання митного кордону України майном, відповідно до ч. 1 ст. 139 даного Кодексу, та/або робочою силою. Відповідно до ч. 1 ст. 139 майном визнається сукупність речей та інших цінностей (включаючи нематеріальні активи), які мають вартісне визначення, виробляються чи використовуються у діяльності суб'єктів господарювання та відображаються в їх балансі або враховуються в інших передбачених законом формах обліку майна цих суб'єктів [7].

Основним спеціальним нормативно-правовим актом, що регулює зовнішньоекономічну діяльність, є Закон України від 16 квітня 1991 р. «Про зовнішньоекономічну діяльність», який визначає принципи зовнішньоекономічної діяльності, окреслює коло iĭ суб'єктів, називає види зовнішньоекономічної діяльності, закріплює основи ііі регулювання, передбачає встановлення спеціальних правових режимів зовнішньоекономічної діяльності, а також містить норми щодо відповідальності учасників зовнішньоекономічної діяльності та захисту їх прав та інтересів. Саме з прийняттям даного закону зовнішньоекономічна діяльність в Україні вперше одержала правовий статус.

Відповідно до ст. 1 Закону України «Про зовнішньоекономічну діяльність» (далі - ЗУ «Про ЗЕД») зовнішньоекономічна діяльність - діяльність суб'єктів господарської діяльності України та іноземних суб'єктів господарської діяльності, побудована на взаємовідносинах між ними, що має місце як на території України, так і за ії межами. Діяльність суб'єктів зовнішньоекономічної діяльності в межах території України регулюється чинними нормативно-правовими актами України та відповідними нормами міжнародного права. Також відповідно до зазначеного у ст. 2 ЗУ «Про ЗЕД» принципу захисту інтересів суб'єктів зовнішньоекономічної діяльності, який полягає у тому, що Україна як держава: забезпечує рівний захист інтересів всіх суб'єктів зовнішньоекономічної діяльності та іноземних суб’єктів господарської діяльності на її території згідно з законами України; здійснює рівний захист всіх суб'єктів зовнішньоекономічної діяльності України за межами України згідно з нормами міжнародного права; здійснює захист державних інтересів України як на іiї території, так і за їі межами лише відповідно до законів України, умов підписаних нею міжнародних договорів та норм міжнародного права [8].

Проте, як вже було зазначено, безпосередньо різні аспекти зовнішньоекономічних відносин регулюються численною кількістю суперечливих за своїм змістом нормативно-правових актів, у яких також існують і явні прогалини.

У Законі України «Про міжнародне приватне право» зосереджені основні нормативно-правові засади регулювання зовнішньоекономічної діяльності, саме тому Закон України «Про зовнішньоекономічну діяльність» мав би концентрувати у собі також публічно-правові аспекти, зокрема основні механізми реалізації засобів державного регулювання відносин у цій сфері. Однак на сучасному етапі розвитку науки господарського права відсутні грунтовні дослідження особливостей взаємного впливу та зв'язку зазначених нормативно-правових актів, а також їх зв'язки із Господарським кодексом України [9]. Таким чином, залишається актуальною проблема впорядкування внутрішнього законодавства, що регулює відносини у сфері зовнішньоекономічної діяльності.

Важливою подією стало набуття Україною членства у Світовій організації торгівлі (далі - СОТ). 10 квітня 2008 р. Верховною Радою України було прийнято Закон України «Про ратифікацію Протоколу про вступ України до СОТ» (далі - Протокол), а також відповідну низку законів, що були прийняті в пакеті з ратифікацією Протоколу [10].

Необхідність проведення гармонізації законодавства виникла у результаті дослідження зовнішніх процесів у контексті міжнародної інтеграції України. Дана необхідність спричинена вимогами, 
що були висунуті Європейським Союзом, а саме адаптації національного законодавства України до світових стандартів. Дана вимога може бути успішно виконаною тільки у разі, коли законодавство країн кандидатів чи країни, які вже мають членство, вже досягло певного рівня узгодженості та відповідності. «Адаптація законодавства України до законодавства ЄС є однією з основних складових процесу інтеграції України в СС, що $€$ пріоритетним напрямком української зовнішньої політики [11].

Відповідно до п. 4 ст. 16 Марракеської угоди про заснування СОТ кожна країна повинна забезпечити відповідність своїх нормативно-правових актів та адміністративних процедур ії зобов'язанням, передбаченим угодами СОТ. У п. 2 ст. 15 зазначено, що кожен член СОТ повинен реалізовувати такі поступки та зобов'язання по багатосторонніх торговельних угодах, які він повинен був реалізовувати з часу набуття чинності даною Угодою [12].

В даному контексті доречно підкреслити, що світові інтеграційні процеси суттєво впливають на розвиток вітчизняного та зарубіжного господарського законодавства на формування специфіки їх зовнішньоекономічних відносин.

Висновок. Проаналізувавши норми чинного законодавства України у сфері здійснення зовнішньоекономічної діяльності, чітко постає проблема необхідності впорядкування національного законодавства, що регулює зазначену сферу правовідносин. Чинне законодавство України, що регулює зовнішньоекономічну діяльність, містить ряд недоліків, серед них наступні: недостатня системність нормативно-правових актів, наявність значної кількості нормативно-правових актів, що регулюють вищезазначену сферу правовідносин, наявність численних прогалин та колізій правових норм. Зважаючи, що суб'єктами зовнішньоекономічної діяльності також є іноземні суб'єкти господарської діяльності, узгодження потребує вітчизняна законодавча база із відповідними нормами та нормативно-правовими актами інших країн. Дане завдання має бути реалізоване із врахуванням того, щоб при спробі адаптації українського законодавства та запозичення із подальшим впровадженням закордонної практики не склалася ситуація, коли впроваджені зміни у результаті спричинять протилежний результат. Такі дії треба здійснювати, виходячи із специфіки внутрішнього законодавства та господарської діяльності з метою збереження норм, ефективність яких була доведена на практиці.

\section{Список використаних джерел}

1. Вишняков A. K. Регулирование внешнеэкономической деятельности в Украине. - Харьков : Одиссей, 2005. $-256 \mathrm{c}$.

2. Коломацька С. П. Зовнішньоекономічна діяльність в Україні: правове регулювання та гарантії здійснення. К. : Професіонал, 2004. - 288 с.

3. Костюченко О. А. Валютне законодавство України. - К. : Атіка, 2006. -304 с.

4. Георгіаді Н. Г., Князь С. В. Регулювання зовнішньоекономічної діяльності. - Львів : Львівська політехніка, 2004. - $196 \mathrm{c}$.

5. Регулювання зовнішньоекономічної діяльності в Україні / За ред. А. А. Мазаракі. - К. : КНТЕУ, 2003. - 272 с.

6. Державне управління: теорія і практика / За заг. ред. проф. В. Б. Авер'янова. - К. : Юрінком Інтер, 1998. - 432 с.

7. Господарський кодекс України : Закон України від 16.01.2001 р. № 436-IV // Відомості Верховної Ради України. - 2003. - № 18, №№ 19-20, № 21-22. - Ст. 144.

8. Про зовнішньоекономічну діяльність : Закон України від 16.04.1991 р. № 959-ХІІ// Відомості Верховної Ради України. - 1991. - № 29. - Ст. 377.

9. Про міжнародне приватне право : Закон України від 23.06.2005 р. № 2709-IV //Відомості Верховної Ради України. - 2005. - № 32. - Ст. 422.

10. Про ратифікацію Протоколу про вступ України до Світової організації торгівлі: Закон України від 10.04.2008 p. № 250-VI // Офіційний вісник України. - 2008. - № 31. - Ст. 960.

11. Матеріали Урядового порталу [Електронний ресурс]. - Режим доступу : http://www.kmu.gov.ua

12. Маракешское Соглашение о создании Всемирной торговой организации от 15.04.1994 г. // Українська інвестиційна газета. - 2006. - № 29.

13. Концепщия модернизации хозяйственного законодательства на базе Хозяйственного кодекса Украины (Проект) // Экономика и право. - 2006. - № 2. - С. 5-15.

14. Про засади державної регуляторної політики у сфері господарської діяльності : Закон України від 11.09.2003 р. № 1160-IV // Відомості Верховної Ради України. - 2004. - № 9. - Ст. 79. 


\section{References}

1. Vyshniakov A. K. Rehulyrovanye vneshneэkonomycheskoi deiatelnosty v Ukrayne. - Kharkov : Odyssei, 2005. $256 \mathrm{~s}$.

2. Kolomatska S. P. Zovnishnoekonomichna diialnist v Ukraini: pravove rehuliuvannia ta harantii zdiisnennia. - K. : Profesional, 2004. - $288 \mathrm{~s}$

3. Kostiuchenko O. A. Valiutne zakonodavstvo Ukrainy. - K. : Atika, 2006. -304 s.

4. Heorhiadi N. H., Kniaz S. V. Rehuliuvannia zovnishnoekonomichnoi diialnosti. - Lviv : Lvivska politekhnika, 2004. - $196 \mathrm{~s}$.

5. Rehuliuvannia zovnishnoekonomichnoi diialnosti v Ukraini / Za red. A. A. Mazaraki. - K. : KNTEU, 2003. - 272 s.

6. Derzhavne upravlinnia: teoriia i praktyka / Za zah. red. prof. V. B. Averianova. - K. : Yurinkom Inter, 1998. - $432 \mathrm{~s}$.

7. Hospodarskyi kodeks Ukrainy : Zakon Ukrainy vid 16.01.2001 r. № 436-IV // Vidomosti Verkhovnoi Rady Ukrainy. 2003. - № 18, №№ 19-20, №№ 21-22. - St. 144.

8. Pro zovnishnoekonomichnu diialnist : Zakon Ukrainy vid 16.04.1991 r. № 959-XII// Vidomosti Verkhovnoi Rady Ukrainy. - 1991. - № 29. - St. 377.

9. Pro mizhnarodne pryvatne pravo : Zakon Ukrainy vid 23.06.2005 r. № 2709-IV //Vidomosti Verkhovnoi Rady Ukrainy. - 2005. - № 32. - St. 422.

10. Pro ratyfikatsiiu Protokolu pro vstup Ukrainy do Svitovoi orhanizatsii torhivli : Zakon Ukrainy vid 10.04.2008 r. № 250-VI // Ofitsiinyi visnyk Ukrainy. - 2008. - № 31. - St. 960.

11. Materialy Uriadovoho portalu [Elektronnyi resurs]. - Rezhym dostupu : http://www.kmu.gov.ua

12. Marakeshskoe Sohlashenye o sozdanyy Vsemyrnoi torhovoi orhanyzatsyy ot 15.04 .1994 hoda // Ukrainska investytsiina hazeta. - 2006. - № 29.

13. Kontseptsyia modernyzatsyy khoziaistvennoho zakonodatelstva na baze Khoziaistvennoho kodeksa Ukrayny (Proekt) // Ekonomyka y pravo. - 2006. - № 2. - S. 5-15.

14. Pro zasady derzhavnoi rehuliatornoi polityky u sferi hospodarskoi diialnosti : Zakon Ukrainy vid 11.09.2003 r. № 1160-IV // Vidomosti Verkhovnoi Rady Ukrainy. - 2004. - № 9. - St. 79.

\section{Рубцова-Каменська Г. А. Особливості законодавчого регулювання зовнішньоекономічної діяльності}

Стаття присвячена розгляду чинних нормативно-правових актів, що регулюють правовідносини у сфері здійснення зовнішньоекономічної діяльності, дослідженню особливостей законодавства у даній сфері. У статті здійснено аналіз основних нормативно-правових актів, що регулюють здійснення зовнішньоекономічної діяльності на території України, та запропоновані шляхи вдосконалення нормативно-правового регулювання цієї сфери.

Ключові слова: зовнішньоекономічна діяльність, законодавче регулювання зовнішньоекономічної діяльності, економічна діяльність.

\section{Rubtsova-Kamenska H. A. Features of the legal regulation of foreign economic activity}

This article is devoted to the consideration of the existing legal acts which regulate legal relations in the field of foreign economic activity, the study of the peculiarities of legislation in this area.

In legal literature, external economic activity is considered as activity in the sphere of development of cooperation with other states in the field of trade, economy, technology, culture, tourism. In the opinion of some authors, this is a form of social and industrial relations between individual states, between states and international organizations, between organizations in the sphere of international economic cooperation.

Foreign economic activity is an important element in the development of economic activity in the state. Without foreign economic operations, it is impossible for the state to participate in world trade activities. Legal regulation is one of the main determining factors, which in turn affect the formation of a favorable climate for foreign business entities and the image of the country in general. However, it is important to note that the effectiveness of the activities of non-economic entities depends on the effectiveness of the activity of the system of legal regulation of foreign economic activity. In this connection, it is necessary to systematize the domestic legislation.

The information presented in this article is regarding the analysis of the basic legal acts regulating the implementation of foreign economic activity on the territory of Ukraine and suggests the ways to improve the regulatory and legal framework in this field.

Key words: foreign economic activity, legislative regulation of foreign economic activity, economic activity.

DOI: 10.33.66.3/2524-017X-2019-10-337-340 